Barnes, T. R. E. \& McPhillips, M. A. (1999) Critical analysis and comparison of the side-effect and safety profiles of the new antipsychotics. British journal of Psychiatry, 174 (suppl. 38), 34-43.

Burkhard, P. R., Vingerhoets, F. J. G., Alberque, C., ot al (1999) Olanzapine induced neuroleptic malignant syndrome. Archives of General Psychiatry, 56, 101-102.

Fillce, G. A., McDougall, B. C., Ercan Fang, N., < of (1998) Neuroleptic malignant syndrome associated with olanzapine. Annals of Pharmacotherapy, 32. 1158-1159.

D. Kohen 2nd Floor East Wing, Homerton Hospital, Homerton Row, London E9 6SR

M. F. Bristow Cheam Resource Centre, 671 London Road, North Cheam, Surrey SM3 9DL

\section{Prescribing donepezil in clinical practice}

Sir: We were interested to read the recent editorial on the new treatments for Alzheimer's disease and the account of experiences with these drugs in south Manchester (Burns et al, 1999a). We report here our success in titrating up the dose of donepezil and difficulties in discontinuing treatment.

In Lancaster we have been prescribing donepezil since April 1997 using the Cambridge Cognitive Examination (part of the Cambridge Examination for Mental Disorders of the Elderly; Roth et al, 1986), the Clinicians' Interview-Based Impression of Change (Leber, 1990) and carer report to assess response. We have prescribed for 44 patients so far. The pattern of response has been very similar to that in south Manchester and we can confirm valuable noncognitive response such as improved mood, initiative, confidence and clarity of thought. However, we have had only five drop-outs (in south Manchester one-third of patients dropped out) and we wonder whether our individually tailored flexible way of prescribing donepezil has meant that side-effects were less problematic. We have aimed at $10 \mathrm{mg}$ daily as the optimum dose in all cases in view of the clear doseresponse effect, recently confirmed (Burns et $a l, 1999 b$ ). Using the long half-life (70 hours) of donepezil, it is easy to titrate up slowly from $5 \mathrm{mg}$ to $\mathbf{1 0} \mathrm{mg}$ daily, by using intermediate steps, such as 5, 5, 10 (repeated) $5,10,10$ (repeated) to achieve 10 , 10,10 over weeks. It is important, therefore, that the first prescription for $10 \mathrm{mg}$ daily is dispensed as $2 \times 5 \mathrm{mg}$ to allow for this, and also to allow for a dose reduction to $5 \mathrm{mg}$ daily, if side-effects are really troublesome. If morning diarrhoea is a problem after $10 \mathrm{mg}$ nocte, $5 \mathrm{mg}$ twice daily has resolved the problem.

Another difference from the south Manchester experience is that we have had some problems discontinuing donepezil. In three cases discontinuation has been followed by some of the following: increased disorientation with loss of familiarity, agitation and restlessness, especially nocturnal, with visual hallucinations, lowering of mood, anxiety, uncooperativeness and carer distress. In future, we plan to reduce the dose to $5 \mathrm{mg}$ some weeks prior to stopping it altogether.

We wonder whether these new anticholinesterase drugs may have a role in future as an alternative to neuroleptics in managing behavioural disturbance associated with Alzheimer's disease.

Burns, A., Russell, E. \& Page, S. (1999a) New drugs for Alzheimer's disease. British journal of Psychiotry, 175. $476-479$.

-, Rossor, M., Hecker, J., et al and the International Donepedil Study Group (1999b) The effects of donepezil in Alzheimer's disease - results from a multinational trial. Dementia and Geriatric Cognitive Disorders, 10, 237-244.

Leber, P. (1990) Guidelines for the Clinical Evaluation of Antidementia Drugs. Washington, DC: Food and Drug Administration.

Roth, M., Tym, E., Mountjoy, C. Q., et al (1986) CAMDEX. A standardised instrument for the diagnosis of mental disorder in the elderly with special reference to the early detection of dementia. British journal of Psychiatry, 149, 698-709.

M. A. Watts-Tobin Department of Old Age Psychiatry, Lancaster Moor Hospital, Lancaster LAI 3JR

N. Horn University of Manchester Neuroscience and Psychiatry Unit, Stopford Building, Oxford Road, Manchester MI3 9PT

\section{More trouble with ethics committees}

Sir: I applied for permission to conduct research within two National Health Service trusts, each covered by two local research ethics committees (LRECs). The responses were: (a) trust 1: one LREC approved, the other refused on the grounds that the study contravened the Data Protection Act; (b) trust 2: one LREC approved, the other approved on condition that patient consent was obtained. I attempted to clarify: first, how to proceed, given these contradictory decisions; second, why consent was required (given that the intention was to obtain anonymised patient information from clinicians without patient contact) and third, whether or not the information required contravened the Data Protection Act.

According to the health authority, the situation arose because LRECs had failed to merge alongside their corresponding trusts. The health authority also noted that I need only have applied to one LREC per trust, although this was not clarified on application. The health authority advised me to request information about only those patients who resided in geographical areas covered by the LRECs who gave approval. Notwithstanding the effects on the study, this meant telling clinicians in trust 1 that it was only ethical for them to give information about patients from certain geographical areas, and in trust 2 that only those patients from certain geographical areas need to consent. The Department of Health and the health authority could not advise about the consent issue and noted that decisionmaking had been devolved entirely to the LRECs. The Data Protection Registrar's office commented that the information I required did not contravene the Data Protection Act.

It has long been recognised that LRECs demonstrate high degrees of practical and methodological diversity (Garfield, 1995; Middle et al, 1995). Although it must be accepted that there will be some variation due to local needs (Gilbert et al, 1989), it is reasonable to expect that LRECs, particularly those covering the same local area, will strive for both internal and external consistency. The Department of Health, research councils and the Data Protection Registrar should work together to provide national guidelines for LRECs, both in the public interest and in the interests of research. The LRECs involved in my case have now decided to review their procedures, but too late to benefit my study.

Garfield, P. (1995) Cross district comparison of applications to research ethics committees. British Medical Journal, 311, 660-66I.

CIIbert, C., Fulford, K. W. M. \& Parber, C. (1989) Diversity in the practice of district ethics committees. British Medical journal, 299, 1437-1439.

Middle, C., Johnsoon, A., Petty, T., et of (1995) Ethics approval for a national postal survey: recent experience. British Medical Journal, 311, 659-660.

A. Cohen Department of Clinical Psychology, Salomons Centre, Broomhill Road, Southborough, Tunbridge Wells, Kent TN3 0TG 